\title{
New statistical approaches to analyze data from intercropping experiments
}

\section{Novas abordagens estatísticas na análise de experimentos de consórcios}

José Hamilton da Costa Filho ${ }^{1}$, Luis Antônio dos Santos Dias ${ }^{2}$, Larissa de Oliveira Fontes ${ }^{3}$, Gerson dos Santos Lisboa ${ }^{4}$, José Eudes da Silva Souza ${ }^{1}$

\begin{abstract}
Discussed this and other statistical methods for processing simulated data from the Jatropha $\mathrm{x}$ Cowpea intercropping system, in order to compare them with others and with the conventional method, and to recommend a general application method in experiments with intercropping systems. The experimental design was randomized blocks with four replications. The treatments were arranged in a $2 \times 7$ factorial scheme, corresponding to two levels ( 90 and $100 \%$ of the recommended population in sole cropping RPSC) of jatropha, with 4 × 2 m and seven levels (40;50; 60; 70; 80; 90 and 100\% of RPSC) of cowpea. The variables analyzed in jatropha were intercropping yield $\left(\mathrm{t} \mathrm{ha}^{-1}\right)$, mass of seeds $\left(\mathrm{t} \mathrm{ha}^{-1}\right)$, oil yield $\left(\mathrm{L} \mathrm{ha}^{-}\right.$ $\left.{ }^{1}\right)$ and gross income $(\mathrm{R} \$)$. In cowpea, the variables were yield $\left(\mathrm{t} \mathrm{ha}^{-1}\right)$ and gross income $(\mathrm{R} \$)$. The evaluated methodologies were ANOVA with application of Tukey test, multivariate analysis of variance, bivariate analysis of variance, land use efficiency index (LUE), competitiveness index, DEA efficiency index, multicriteria decision support analysis of Copeland and Ward's hierarchical cluster analysis. The

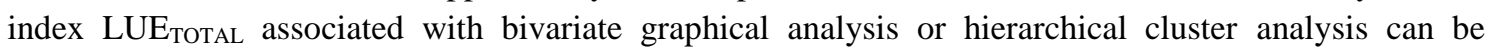
successfully applied in the processing of data from any intercropping system. Thus, LUE $\mathrm{TOTAL}_{\text {and }}$ multivariate analysis are recommended as complementary methods.
\end{abstract}

Keywords: Land use efficiency index; Data envelopment analysis; Multicriteria decision support method; Bivariate analysis of variance; Univariate analysis of variance;

\section{RESUMO}

Discutiu-se este e outros métodos estatísticos de processamento para dados simulados do sistema consorciado Jatropha x Feijão-caupi, a fim de compará-los com o método convencional, objetivando recomendar um método de aplicação geral em experimentos com sistemas consorciados. O delineamento experimental foi em blocos casualizados com quatro repetições. Os tratamentos foram arranjados em esquema fatorial $2 \times 7$, correspondendo a dois níveis (90 e 100\% da população recomendada em monocultivo - RPSC) de pinhão-manso, com 4 x 2 m, e sete níveis (40; 50; 60; $70 ; 80 ; 90$ e 100\% de RPSC) de feijão-caupi. As variáveis analisadas no pinhão-manso foram produtividade em consórcio ( $t$ ha $^{-}$

\footnotetext{
${ }^{1}$ Universidade Federal do Rio Grande do Norte (UFRN)

*E-mail: hamilton_costa@yahoo.com.br

${ }^{2}$ Universidade Federal de Viçosa (UFV)

${ }^{3}$ Universidade Federal do Piauí (UFPI)

${ }^{4}$ Universidade Federal de Goiás (UFG)
} 
${ }^{1}$ ), massa de sementes $\left(t \mathrm{ha}^{-1}\right)$, produtividade de óleo $\left(\mathrm{L} \mathrm{ha}^{-1}\right)$ e renda bruta ( $\left.\mathrm{R} \$\right)$. No feijão-caupi, as variáveis foram produtividade $\left(t \mathrm{th}^{-1}\right)$ e renda bruta $(\mathrm{R} \$)$. As metodologias avaliadas foram ANOVA com aplicação do teste de Tukey, análise multivariada de variância, análise bivariada de variância, índice de eficiência do uso da terra (UET), índice de competitividade, índice de eficiência DEA, análise multicritério de suporte à decisão de Copeland e análise hierárquica de cluster de Ward. O índice UET TOTAL associado à análise gráfica bivariada ou análise hierárquica de agrupamento pode ser aplicado com sucesso no processamento de dados de qualquer sistema consorciado.

Palavras-chave: Índice de eficiência do uso da terra; Análise envoltória de dados; Método multicritério de apoio à decisão; Análise de variância bivariada; Análise de variância univariada;

\section{INTRODUCTION}

Definition of hypotheses, planning, experiment conduction and data analysis are essential procedures for the reliability of results obtained in an experiment. Experimental design and analytical procedures for data processing are defined in the experimental planning (DIAS; BARROS, 2009). The previous definition of these procedures is simplified for the basic designs and their arrangements. However, such definition can be complex in the evaluation of more than one source of variation in the same experiment. Tests with intercropped species generate controversies about the definition of the most adequate methodology of data processing.

Intercropping consists in the exploitation of two or more plant species (treatments) simultaneously in the same experimental plot. Studies on the evaluation of methods to determine the efficiency of intercropping systems are recent and scarce. In general, the methods are non-parametric and multivariate. This is due to the multivariate nature of the data resulting from the joint evaluation of agronomic and economic parameters (BEZERRA NETO et al., 2007a). Contrasting with the parametric methods presented by Federer (1993), the statistical analyses at plot level with data envelopment analysis (DEA) was suggested by Bezerra Neto et al. (2007a). The use of this method considers the probability of existence of positive or negative correlation between plots. Conversely, analytical methods that use only the arithmetic mean to process data from intercropping systems are not robust (MELO et al., 2005).

Bezerra Neto et al. (2007a), Bezerra Neto et al. (2007b) and Bezerra Neto et al. (2007c) observed, respectively, effectiveness and ease in the utilization of the DEA method, as well as robustness of the bivariate analysis of variance; viability of the 
multicriteria decision support method and of the utilization of agro-economic indicators for biological productivity of intercropping systems. The recommended methods, except that of bivariate analysis, are object of study of the functional relation between resources and products in production engineering. In plant science, there is a lack of application of these methods to process data from intercropping systems.

This study aimed to evaluate new analytical methods to process simulated data of an intercropping system of a perennial species (Jatropha curcascurcascurcas L.) and an annual species [(Vigna unguiculata (L.) Walp.)], and to recommend one or more of them.

\section{MATERIAL AND METHODS}

The experimental design used in the simulation was randomized complete blocks, with four replications. The simulated treatments were arranged in a $2 \times 7$ factorial scheme. The first factor corresponded to two levels (90 and 100\%) relative to the recommended population for the sole cropping (RPSC) of the perennial species, at 4 x $2 \mathrm{~m}$ spacing, and for the oilseed crop Jatropha (Jatropha curcascurcascurcas L.) (DIAS et al., 2007). The second factor was composed of seven levels (40, 50, 60, 70, 80, 90 and 100\% RPSC), whose standard was 50,000 plants, as recommended for cowpea [(Vigna unguiculata (L.) Walp.)] (CARDOSO et al., 1997).

The variables analyzed in $J$. curcas were yield in intercropping $\left(\mathrm{t} \mathrm{ha}^{-1}\right)$, mass of seeds $\left(\mathrm{t} \mathrm{ha}^{-1}\right)$, oil yield $\left(\mathrm{L} \mathrm{ha}^{-1}\right)$, based on the maximum content $(38.9 \%)$ reported by Kaushik et al. (2007), and gross income, estimated from R $\$ 1.85 \mathrm{~L}^{-1}$ of oil (BARROSO et al., 2014). In the cowpea crop, the analyzed variables were yield and gross income, estimated from the value of $\mathrm{R} \$ 2.30 \mathrm{~kg}^{-1}$.

The experimental data were obtained by simulation using the rnorm() function of the $\mathrm{R}$ software version 3.2.0. The function was entered into the expression $y<-$ matrix $(\operatorname{rnorm}(()$, mean $=(), s d=\operatorname{sqrt}()))$ to obtain the estimated values of the plots, where $\mathrm{y}$ is a vector of four pseudo-random numbers, mean is the mean established and $s d=s q r t$ corresponds to the variance in the normal distribution, so that the distribution of plots ( $\left.\mathrm{Y}_{\mathrm{i}}\right)$ in each treatment is approximately normal, i.e., $\left(\mathrm{Y}_{11}, \mathrm{Y}_{12}, \ldots, \mathrm{Y}_{27}\right) \sim \mathrm{N}\left\{\mu, \sigma^{2}\right\}$.

For the utilization of the function rnorm(), the mean yields of treatments with $J$. curcas in intercropping and the respective variances $\left(\widehat{\sigma}^{2}=1.00\right.$ and $\left.\widehat{\sigma}^{2}=0.01\right)$ were arbitrarily determined. The maximum yield of $J$. curcas in intercropping corresponded 
to the mean yield in sole cropping $\left(5 \mathrm{t} \mathrm{ha}^{-1}\right)$ (TEIXEIRA, 2005). The maximum yield for cowpea, considering the grain yield in the rainfed cultivation in the Piauí state, was approximately $0.03 \mathrm{t} \mathrm{ha}^{-1}$ (IBGE, 2006). The mean yields of J. curcas with 90 and $100 \%$ RPSC in intercropping with 100, 90, 80, 70, 60, 50 and 40\% RPSC of cowpea, were respectively $\mathrm{T} 1(\overline{\mathrm{X}}=2.39), \mathrm{T} 2(\overline{\mathrm{X}}=2.66), \mathrm{T} 3(\overline{\mathrm{X}}=2.95), \mathrm{T} 4(\overline{\mathrm{X}}=3.28), \mathrm{T} 5(\overline{\mathrm{X}}=$ 3.65), T6 ( $\overline{\mathrm{X}}=4.05), \mathrm{T} 7(\overline{\mathrm{X}}=4.50), \mathrm{T} 8(\overline{\mathrm{X}}=2.66), \mathrm{T} 9(\overline{\mathrm{X}}=2.95), \mathrm{T} 10(\overline{\mathrm{X}}=3.28)$, $\mathrm{T} 11(\overline{\mathrm{X}}=3.65), \mathrm{T} 12(\overline{\mathrm{X}}=4.05), \mathrm{T} 13(\overline{\mathrm{X}}=4.50)$ and $\mathrm{T} 14(\overline{\mathrm{X}}=5.00)$. A loss of $10 \%$ in $J$. curcas yield for every $10 \%$ increment in cowpea population was arbitrarily considered.

The statistical methods used for data processing were univariate analysis of variance (ANOVA) (FEDERER, 1993; FISHER, 1971), with Tukey test $(\mathrm{p}<0.05)$, multivariate analysis of variance (MANOVA), bivariate analysis of variance (FEDERER, 1993; PEARCE; GILLIVER, 1979), land use efficiency index (LUE) of Willey (1979), index of competitiveness (IC) of Willey and Rao (1981), DEA (Data Envelopment Analysis) efficiency index of Charnes and Cooper (1962), applied to the treatment means after the ANOVA, multicriteria decision support analysis of Copeland and Ward's hierarchical cluster analysis (WARD, 1963).

The univariate analysis of variance (ANOVA) and Tukey test were processed with the R software version 3.2.0 (R Core Team, 2014). Bivariate analysis of variance was conducted using the statistical module of Excel for processing the method of Pearce and Gilliver (1979). The variables $\mathrm{Y}_{\mathrm{A}}$ and $\mathrm{Y}_{\mathrm{B}}$ relative to the yields in the intercropping of $J$. curcas (YJIC) and cowpea (YCIC) were transformed. The mean square of the residual of the ANOVA of YJIC (MSYJIC), mean square of the residual of the ANOVA of YCIC (MSYCIC) and mean product of the residual of the analysis of yields of Jatropha and cowpea in intercropping (MPYJICCIC) were used (1):

(1) MPYJICCIC $=\frac{\text { MSYCIC }- \text { MSYJIC }- \text { MSYJICCIC }}{2}$

The variables $\mathrm{X}_{\mathrm{A}}$ and $\mathrm{X}_{\mathrm{B}}$, not correlated, were, respectively obtained by 2 and 3:

(2) $X_{\mathrm{A}}=\frac{\mathrm{Y}_{\mathrm{A}}}{\sqrt{\mathrm{MSYJIC}}} ;$ (3) $\mathrm{X}_{\mathrm{B}}=\frac{\mathrm{Y}_{\mathrm{A}}-\left(\text { MPYJICCIC } \mathrm{Y}_{\mathrm{B}}\right)}{\sqrt{\frac{\text { MSYCIC }- \text { MPYJICCIC }}{\text { MSYJIC }}}}$

meeting the restrictions of orthogonality $\widehat{\sigma}_{\mathrm{X}_{\mathrm{A}}}^{2}=\widehat{\sigma}_{\mathrm{X}_{\mathrm{B}}}^{2}=1$ and $\operatorname{COV}\left(\mathrm{X}_{\mathrm{A}}, \mathrm{X}_{\mathrm{B}}\right)=0$. 
The efficiency indices based on efficient land use (LUE) (WILLEY, 1979) were calculated using Excel. LUE was obtained by 4:

(4) $\mathrm{LUE}=\frac{\mathrm{Y}_{\mathrm{YJIC}}}{\mathrm{Y}_{\mathrm{YJSC}}}+\frac{\mathrm{Y}_{\mathrm{YCIC}}}{\mathrm{Y}_{\mathrm{YCSC}}}$

where, $Y_{\text {YJIC }}$ is the grain yield of $J$. curcas in intercropping and Y YJSC $_{\text {is }}$ its yield in sole

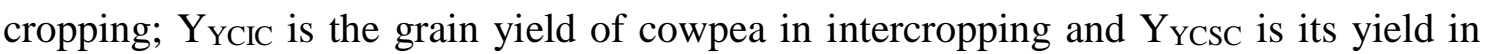
sole cropping. The partial LUE of $J$. curcas (LUEPARTJ) and cowpea (LUEPARTC) were respectively obtained by 5 and 6 :

(5) LUE $_{\text {PARTJ }}=\frac{Y_{\text {YJIC }}}{Y_{Y J S C}} ;(6)$ LUE $_{\text {PARTC }}=\frac{Y_{\text {YCIC }}}{Y_{Y C S C}}$

where, LUEPART close to 1 indicates efficiency of the intercropping system in comparison to the sole cropping system. The index of competitiveness between crops of Willey and Rao (1981) was obtained by 7 :

(7) $I C=\frac{\text { LUE }_{\text {PARTC }}}{\text { LUE }_{\text {PARTJ }}}$

The productive efficiency of each plot was obtained using the DEA model with constant returns to scale (COOPER et al., 2004), using the application ISYDS Integrated system for decision support (ANGULO MEZA et al., 2005a), with unit inputs (LOVELL; PASTOR, 1999). For each mean of treatments, model 8 was processed:

(8) $\operatorname{Max}_{h_{o}}=\frac{\sum_{j=1}^{r} \mathrm{u}_{\mathrm{j}} y_{j k}}{\sum_{i=1}^{S} v_{i} \mathrm{x}_{\mathrm{ik}}}$

with restrictions $(9,10$ and 11$)$ :

(9) $\frac{u_{j} y_{j k}}{v_{i} \mathrm{x}_{\mathrm{ik}}} \leq 1$; (10) $v_{i} \geq 0$; (11) $u_{j} \geq 0$

where, $v_{i}$ and $u_{j}$ are the weights of inputs (resources or treatments) $i(i=1, \ldots, r)$ and outputs (products or variables) $\mathrm{j}=1, \ldots, \mathrm{s}$, respectively. The unknowns of the model are $x_{i k}$ : value of the resource $i(i=1 \ldots s)$ for each plot $k(k=1 \ldots n) ; y_{j k}$ : value of the product $j$ $(\mathrm{j}=1 \ldots \mathrm{r})$ (output of the DMU), for the plot $\mathrm{k}(\mathrm{k}=1, \ldots, \mathrm{O})$; and $\mathrm{O}$ is the plot in analysis. Maximum efficiency was determined by linearizing the fractional model (CHARNES; COOPER, 1962) (12): (12) $\mathrm{MaxZ}=\sum_{\mathrm{j}=1}^{\mathrm{r}} \mu_{\mathrm{j}} \mathrm{y}_{\mathrm{jo}}$; with restrictions to the model $(13,14$, 15 and 16): (13) $\sum_{\mathrm{i}=1}^{\mathrm{s}} \mathrm{V}_{\mathrm{i}} \mathrm{x}_{\mathrm{io}}=1$; (14) $\sum_{\mathrm{j}=1}^{\mathrm{r}} \mu_{\mathrm{j}} \mathrm{y}_{\mathrm{jk}}-\sum_{\mathrm{j}=1}^{\mathrm{s}} \mathrm{V}_{\mathrm{i}} \mathrm{x}_{\mathrm{ik}} \leq 0$; and (15) $\mu_{\mathrm{i}} \geq 0$ and (16) $V_{i} \geq 0$. To enter the variables into the model, orthogonal transformation was carried out through the method of Pearce and Gilliver (1979). 
Multicriteria analysis through the Copeland method was performed with the software Preferências Ordinais Agregadas - WebPROA. Pair-wise comparison of means was made and the Condorcet decision matrix was obtained for 14 treatments. Each element $a_{i j}$ of the matrix was obtained by attributing 0 when the element $\mathrm{i}$ (for $\mathrm{i}=$ $1,2, \ldots, \mathrm{i}$-th alternative) is equal to $\mathrm{j}(\mathrm{j}=1,2, \ldots, \mathrm{j}$-th alternative $) ; 1$ when the element $\mathrm{i}$ is preferred over $\mathrm{j}$ and -1 when an element $\mathrm{i}$ is preferred over $\mathrm{j}$. Ranks were defined based on the sums of the lines of the Condorcet decision matrix for each treatment. The method was applied to 14 criteria referring to the treatments $(\mathrm{T} 1, \mathrm{~T} 2, \ldots, \mathrm{T} 14)$.

Cluster analysis was carried out with the hierarchical method of Ward (1963), using the R software version 3.2.0. (R Core Team, 2014). All the processing was carried out at the data laboratory of the Federal University of Piauí (UFPI), Campus Professora Cinobelina Elvas (CPCE), municipality of Bom Jesus, Piauí, Brazil.

\section{RESULTS AND DISCUSSION}

Based on the analysis of variance (ANOVA), the interaction between sole cropping systems of $J$. curcas and cowpea had significant effect ( $\mathrm{p}<0.01)$ on all variables. For J. curcas in intercropping, significant effect occurred on yield, gross income, mass of seeds and oil yield $(\mathrm{p}<0.05)$. For cowpea in intercropping, yield and gross income $(\mathrm{p}<0.01)$ were affected (Table 1$)$.

Table 1 - Summary of analysis of variance and Tukey test for simulated data of J. curcas (JS) and cowpea (CS) in sole cropping and in intercropping (JS x CS)

\begin{tabular}{|c|c|c|c|c|c|c|c|}
\hline \multirow{2}{*}{ SV } & \multirow{2}{*}{$\mathrm{DF}$} & \multicolumn{6}{|c|}{${ }^{1} \mathrm{~F}$} \\
\hline & & YJIC & GIJIC & MSJIC & OYJIC & YCIC & GICIC \\
\hline J. curcas (JS) & 1 & $7.41 *$ & $7.41 *$ & $7.38^{*}$ & $7.41^{*}$ & $124.35 * *$ & $126.39 * *$ \\
\hline Cowpea (CS) & 6 & 1.45 & 1.45 & 1.46 & 1.45 & $4.95^{* *}$ & $4.99 * *$ \\
\hline JS x CS & 6 & $6.96 * *$ & $6.96 * *$ & $6.97 * *$ & $6.96 * *$ & $5.42 * *$ & $5.29 * *$ \\
\hline Blocks & 3 & 0.80 & 0.80 & 0.81 & 0.80 & 0.22 & 0.306 \\
\hline Residual & 39 & - & - & - & - & - & - \\
\hline \multirow{2}{*}{$\mathrm{CP}(\%)$} & \multicolumn{2}{|c|}{ YJIC } & \multicolumn{3}{|c|}{ MSJIC } & \multicolumn{2}{|l|}{ OYJIC } \\
\hline & ${ }^{2} \mathrm{I}$ & ${ }^{3} \mathrm{II}$ & $\mathrm{I}$ & & & $\mathrm{I}$ & II \\
\hline 100 & $4 \mathrm{aB}$ & $2.27 \mathrm{aC}$ & $1.33 \mathrm{aB}$ & & & $53.51 \mathrm{aB}$ & $72.52 \mathrm{aC}$ \\
\hline 90 & $6 \mathrm{aB}$ & $3.31 \mathrm{aBC}$ & $1.66 \mathrm{aB}$ & 2.1 & & $67.21 \mathrm{aB}$ & $86.82 \mathrm{aBC}$ \\
\hline
\end{tabular}




\begin{tabular}{ccccccc}
80 & $3.12 \mathrm{aAB}$ & $3.83 \mathrm{aABC}$ & $2.03 \mathrm{aAB}$ & $2.49 \mathrm{aABC}$ & $81.97 \mathrm{aAB}$ & $100.59 \mathrm{aABC}$ \\
70 & $3.78 \mathrm{aAB}$ & $3.91 \mathrm{aABC}$ & $2.27 \mathrm{aAB}$ & $2.54 \mathrm{aABC}$ & $91.74 \mathrm{aAB}$ & $102.69 \mathrm{aABC}$ \\
60 & $3.52 \mathrm{aAB}$ & $3.92 \mathrm{aABC}$ & $2.29 \mathrm{aAB}$ & $2.55 \mathrm{aABC}$ & $92.33 \mathrm{aAB}$ & $102.95 \mathrm{aABC}$ \\
50 & $3.52 \mathrm{aAB}$ & $5.09 \mathrm{aAB}$ & $2.46 \mathrm{aAB}$ & $3.30 \mathrm{aAB}$ & $99.15 \mathrm{aAB}$ & $133.44 \mathrm{aAB}$ \\
40 & $5.13 \mathrm{aA}$ & $5.90 \mathrm{aA}$ & $3.37 \mathrm{aA}$ & $3.83 \mathrm{aA}$ & $134.69 \mathrm{aA}$ & $154.95 \mathrm{aA}$ \\
\hline $\mathrm{CP}(\%)$ & \multicolumn{2}{c}{ GIJIC } & & YCIC & \multicolumn{2}{c}{ GICIC } \\
\cline { 2 - 6 }
\end{tabular}

\begin{tabular}{ccccccc}
\cline { 2 - 6 } & I & II & I & II & I & II \\
\hline 100 & $98.99 \mathrm{aB}$ & $134.17 \mathrm{aB}$ & $0.03 \mathrm{aA}$ & $0.02 \mathrm{aC}$ & $443.4 \mathrm{cA}$ & $624 \mathrm{cC}$ \\
90 & $124.34 \mathrm{aB}$ & $160.61 \mathrm{aAB}$ & $0.02 \mathrm{bA}$ & $0.18 \mathrm{aB}$ & $462 \mathrm{bA}$ & $4236 \mathrm{aB}$ \\
80 & $151.64 \mathrm{aAB}$ & $186.09 \mathrm{aAB}$ & $0.02 \mathrm{bA}$ & $0.19 \mathrm{aB}$ & $462 \mathrm{bA}$ & $4434 \mathrm{aB}$ \\
70 & $169.71 \mathrm{aAB}$ & $189.97 \mathrm{aAB}$ & $0.02 \mathrm{bA}$ & $0.21 \mathrm{aB}$ & $498 \mathrm{bA}$ & $4980 \mathrm{aB}$ \\
60 & $170.80 \mathrm{aAB}$ & $190.46 \mathrm{aAB}$ & $0.02 \mathrm{bA}$ & $0.23 \mathrm{aAB}$ & $552 \mathrm{bA}$ & $5520 \mathrm{aAB}$ \\
50 & $183.42 \mathrm{aAB}$ & $246.87 \mathrm{aAB}$ & $0.04 \mathrm{bA}$ & $0.26 \mathrm{aAB}$ & $648 \mathrm{bA}$ & $6240 \mathrm{aAB}$ \\
40 & $249.17 \mathrm{aA}$ & $286.29 \mathrm{aA}$ & $0.02 \mathrm{bA}$ & $0.35 \mathrm{aA}$ & $846 \mathrm{bA}$ & $8460 \mathrm{aA}$ \\
\hline
\end{tabular}

${ }^{1} \mathrm{~F}$ test; * Significant at 0.05 probability level by $\mathrm{F}$ test; ** Significant at 0.01 probability level by $\mathrm{F}$ test; $\mathrm{CP}(\%)$ - cowpea population. ${ }^{2} 90 \%$ of the recommended population of $J$. curcas; ${ }^{3}$ $100 \%$ of the recommended population of J. curcas. JS - J. curcas in sole cropping, CS Cowpea in sole cropping, YJIC - yield of $J$. curcas in intercropping, GIJIC - gross income of $J$. curcas in intercropping, MSJIC - mass of seeds of J. curcas in intercropping, OYJIC - oil yield of $J$. curcas in intercropping, YCIC - yield of cowpea in intercropping and GICIC - gross income of cowpea in intercropping. Means followed by equal letters, lowercase in the row and uppercase in the column, do not differ at 0.05 probability level by Tukey test.

For the interaction, the best yields $\left(\mathrm{t} \mathrm{ha}^{-1}\right)$ of $J$. curcas at 90 and $100 \%$ RPSC were obtained with $40 \%$ RPSC of cowpea. However, there was no statistical difference between both population densities. Yields of J. curcas at 90 and 100\% RPSC were up to 2.5 times higher than the yields with 100\% RPSC of cowpea.

The same contrast was observed for mass of seeds, oil yield and gross income of $J$. curcas in intercropping, because the analysis of biological efficiency of intercropping systems considers yield as a character of main importance. However, some species have particularities that must be considered before the recommendation of an intercropping system. In the case of $J$. curcas, the yield of oil extracted from the seed 
is directly associated with the viability of the system. Therefore, the hypothesis that yield cannot be associated proportionally with the maintenance of the mean oil content in the seeds, after introducing cowpea in the plot, needs to be verified. In the present study, however, the correlation between yield and oil yield of J. curcas in intercropping was $r=0.99$.

The best yields of cowpea were obtained with 40\% RPSC at 90 and $100 \%$ RPSC of J. curcas. Thus, it becomes evident the interference exerted by J. curcas on cowpea yield. On the other hand, the opposite was not true. Interference of the same nature was reported by Matos et al. (2014). Evaluating 4-year-old J. curcas plants spaced by $4 \times 2 \mathrm{~m}$, intercropped with soybean planted at $1 \mathrm{~m}$ from the row of $J$. curcas, these authors observed yield loss of approximately $50 \%$ for soybean. Conversely, Souza et al. (2013) observed loss of approximately $17 \%$ for the bean crop planted at $1.5 \mathrm{~m}$ from the row of 6-month-old $J$. curcas plants, at spacing of $4 \times 2 \mathrm{~m}$. In this case, the shading on the bean crop was reduced and there was a vigorous performance of $J$. curcas.

Intercropping with forage species has also been studied. Nonetheless, as for food crops, it still requires multidisciplinary investigation. In this process, the use of $J$. curcas as energy crop integrating agrosilvicultural and agrosilvopastoral systems represents an alternative for sustainability of the exploitation by family farmers.

Evaluating different arrangements of $J$. curcas plants, Muller et al. (2014) observed greater vegetative development in plants at spacing of $6 \times 3 \mathrm{~m}$. In a subsequent season, greater gain in plant height was obtained at the spacing of $8 \times 2 \mathrm{~m}$. In the evaluated seasons, the intercropping of $J$. curcas $\mathrm{x}$ corn $\mathrm{x}$ pasture led to greater development of $J$. curcas plants with respect to all variables evaluated. Silva et al. (2012) observed viability in the intercropping of grass and leguminous species planted at $0.5 \mathrm{~m}$ from $J$. curcas plants, at spacing of $3 \times 2 \mathrm{~m}$.

The use of phytotechnical and economic variables for the simulation of plots had consistent results. In general, these results were consistent and corroborated those found in the literature. The gain with the prediction of the performance of the 14 combinations tested, without actually having the field experiment, reinforces the accuracy of the technique used. Undoubtedly, the simulation technique adopted can be used as an auxiliary tool to select or exclude similar treatments.

For graphical evaluation, multivariate analysis of variance (MANOVA) was carried out (Table 2). 
Table 2 - Summary of the multivariate analysis of variance of the combined yields of the $J$. curcas $\mathrm{x}$ cowpea intercropping system

\begin{tabular}{lcccc}
\hline SV & ${ }^{1} \Lambda$ (Wilks) & ${ }^{1}$ Pillai & ${ }^{2}$ Approximation & $\operatorname{Pr}>\mathrm{F}$ \\
\hline J. curcas $(\mathrm{JS})$ & 0.34 & 0.66 & 49.00 & 0.0001 \\
Cowpea (CS) & 0.79 & 0.21 & 6.65 & 0.0001 \\
JS x CS & 0.50 & 0.50 & 24.78 & 0.0001 \\
Blocks & 0.97 & 0.03 & 0.83 & 0.4437 \\
\hline
\end{tabular}

${ }^{1}$ Tests for the null hypothesis of the MANOVA; ${ }^{2}$ Approximation of the Snedecor F-test

Based on the tests for the vectors of treatment means, significant differences $(\mathrm{p}<$ $0.01)$ were found by the criteria of Wilks $(\Lambda<1)$ and Pillai for JS and CS yields and for the interaction between the population densities evaluated (JS x CS).

The result of the MANOVA corroborates the one obtained with the ANOVA for the vectors and their interaction. This result allowed the two-dimensional analysis of treatment scores (Figure 1).

Figure 1 - Non-orthogonal coordinates of treatments $\left[\mathrm{T}_{\mathrm{n}}\left(\mathrm{X}_{\mathrm{A}} ; \mathrm{X}_{\mathrm{B}}\right)\right]$ equivalent to the combined yields of YJIC and YCIC [T1 (2.05; 0.74), T2 (2.57; 0.95), T3 (3.13; 1.16), T4 (3.79; 1.41), T5 (3.53; 1.31), T6 (3.53; 1.29), T7 (5.14; 1.92), T8 (2.28; 0.84), T9 (3.32; 1.05), T10 (3.84; 1.24), T11 (3.92; 1.25), T12 (3.93; 1.23), T13 (5.10; 1.64), T14 (5.92, 1.84)] I, II, III and IV: Quadrants one (Q I), two (Q II), three (Q III) and four (Q IV) subdividing the total graph area into four subareas with equal dimensions.

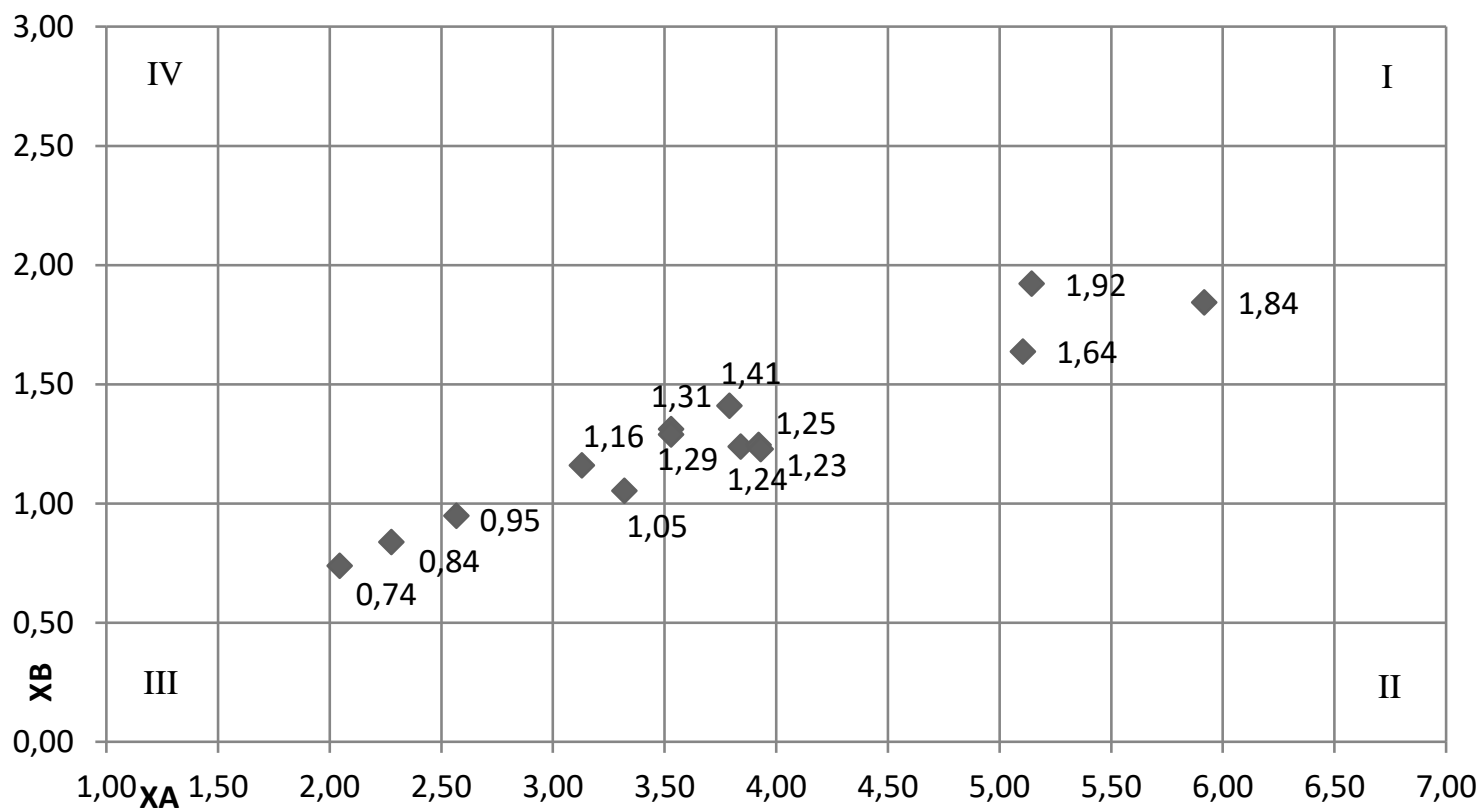

Fonte: the author. 
The descriptive analysis of the dispersion graph (Figure 1) ranks T14 as the best combination for the yield of $J$. curcas in intercropping. Other two treatments were also grouped in Q I (T7 and T13), representing alternatives for gains of yield.

The quality and applicability of the two-dimensional analysis of intercropping data were reinforced by Bezerra Neto et al. (2007a) in a comparative study between analysis methodologies for the carrot $\mathrm{x}$ lettuce system. However, studies evaluating the applicability and efficiency of statistical methods to process data from intercropping systems are still incipient.

Efficiency indices and non-parametric multivariate methods have been used as auxiliary tools for inference on intercropping systems. Indices based on the efficient use of the land exploited per plot (WILLEY, 1979; WILLEY; RAO, 1981) and on data envelopment analysis (CHARNES; COOPER, 1962), as well as the ranking of treatments obtained by the multicriteria decision support method of Copeland (GOMES; BEZERRA NETO, 2008) were obtained in the present study (Table 3).

Table 3 - Intercropping efficiency indices resulting from data envelopment analysis (DEA), efficient land use (LUE $\mathrm{TOTAL}_{\mathrm{TOL}}$ ) and index competitiveness (IC), and classification of Copeland ranks using the variables yield of $J$. curcas in intercropping and gross income of $J$. curcas in intercropping for decision-making.

\begin{tabular}{ccccccc}
\hline \multirow{2}{*}{$\mathrm{CP}(\%)$} & \multicolumn{2}{c}{ DEA } & \multicolumn{2}{c}{ LUE } & \multicolumn{3}{c}{ IC } \\
\cline { 2 - 7 } & I & II & I & II & I & II \\
\hline 100 & 0.35 & 0.47 & 1.00 & 2.05 & 1.76 & 16.85 \\
90 & 0.43 & 0.56 & 1.13 & 7.18 & 1.67 & 15.92 \\
80 & 0.53 & 0.66 & 1.39 & 7.20 & 1.46 & 15.65 \\
70 & 0.59 & 0.66 & 1.40 & 7.68 & 1.25 & 8.96 \\
60 & 0.60 & 0.65 & 1.52 & 8.33 & 1.06 & 8.66 \\
50 & 0.64 & 0.86 & 1.79 & 9.22 & 0.88 & 6.33 \\
40 & 0.87 & 1.00 & 1.90 & 12.53 & 0.74 & 0.74 \\
\hline
\end{tabular}

\begin{tabular}{|c|c|c|c|c|c|c|c|c|c|c|c|c|}
\hline \multicolumn{13}{|c|}{ Copeland ranks } \\
\hline 1 & 2 & 3 & 4 & 5 & 6 & 7 & 8 & 9 & 10 & 11 & 12 & 13 \\
\hline $\mathrm{T} 14$ & $\mathrm{T7}$ & $\mathrm{T} 13$ & $\mathrm{~T} 12$ & $\mathrm{~T} 11$ & $\mathrm{~T} 10$ & T6 & $\mathrm{T} 4$ & T5 & T9 & $\mathrm{T} 3$ & $\begin{array}{ll}\mathrm{T} 8 & \mathrm{~T} 2\end{array}$ & $\mathrm{~T} 1$ \\
\hline
\end{tabular}


The descriptive analysis of the absolute values of the indices DEA, LUE $\mathrm{TOTAL}_{\mathrm{L}}$ and IC kept T14 as the most efficient combination. Consequently, the reduction in the mean efficiency of the treatments was observed as PF (\%) increased. Highest DEA efficiency indices were found for T7 and T14, respectively 0.87 and 1.00.

For LUEтоTAL, T7 and T14 showed the best performance with respect to land use by the intercropped species, respectively 1.90 and 12.53. LUE suggests that the intercropping is advantageous over sole cropping (CAMILI, 2013). In general, LUE is the most used index by researchers to assess the viability of intercropping systems (BEZERRA NETO; GOMES, 2008)

As observed for DEA and LUEтотAL, the best IC values were obtained by the treatments $\mathrm{T} 8$ and $\mathrm{T} 14$, respectively 0.74 and 0.74 . Contrasting with DEA and LUE $_{\text {TотAL, }}$ IC values lower than 1 indicate reduced interference of the secondary crop on the yield of the main one. Nevertheless, Bezerra Neto et al. (2007c) pointed out that IC should not be considered as a single criterion and the intercropping system should have economic viability for both crops.

Bezerra Neto et al. (2007a) highlight that indices resulting from the DEA CCR model have univariate nature and can be processed by parametric techniques. However, this study found that only the absolute values of the indices allowed the ranking of the treatments and that the results did not differ from those obtained with the methods ANOVA, MANOVA and two-dimensional graphic analysis.

The convergent results of the indices are associated with the use of the mean as central tendency statistics of the treatments. LUEтотAL and IC are indices that require strict meeting of parametric assumptions; however, the same does not apply to the DEA index (MELO et al., 2005). According to Melo et al. (2005), DEA models and the multicriteria decision support method of Copeland are non-parametric alternatives for processing (MELO et al., 2005). In the present study, the hypothesis of application of the DEA CCR model to the plots was preferred over treatment means. The procedure was adopted because the experiment was simulated according to an experimental design and met the basic assumptions of ANOVA and MANOVA. Therefore, the processing at plot level would become redundant with the use of mean values.

Lastly, the result of the multicriteria decision support method of Copeland did not differ from those obtained with the other methodologies evaluated. It brought great value to the analysis, considering the obtaining of linear indices through the joint analysis of variables with different natures, in this case, the combination of an economic 
variable (RBPC) and an agronomic variable (RPC). The viability of using this nonparametric technique was also found by Bezerra Neto et al. (2007b) for carrot-lettuce intercropping.

Ultimately, the applicability of the multivariate hierarchical clustering method of Ward was evaluated (Figure 2).

Figure 2 - Dendrograms of Ward's hierarchical clustering for dissimilarity between groups of treatments of $J$. curcas x cowpea obtained respectively by YJIC; YCIC (A) and YJIC; YCIC; MSJIC; OYJIC; GIJ; YCIC and GIC (B)
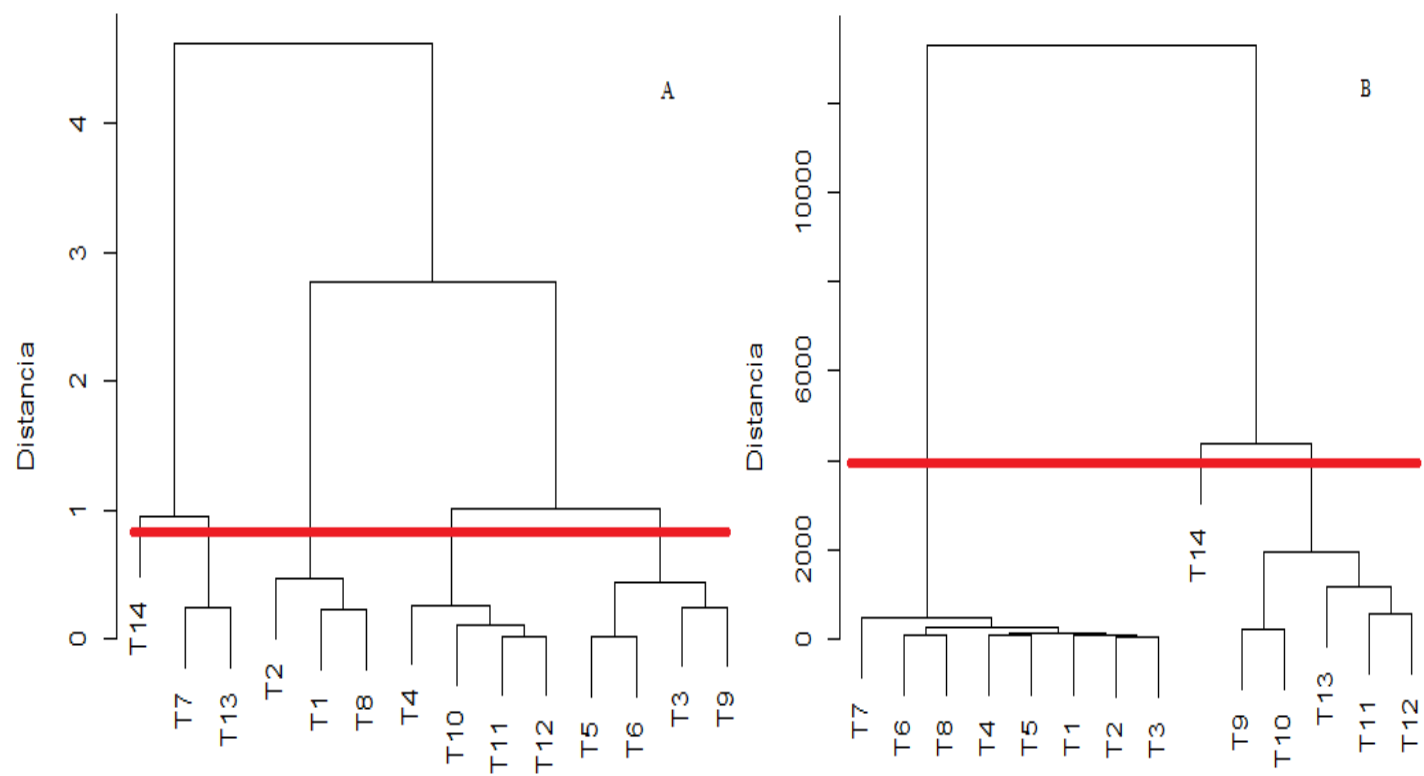

Fonte: the author.

No divergence was observed between the results obtained with the cluster analysis and with the other methodologies evaluated. Among the five groups formed in the dendrogram A, T14 defined group I and had the highest means for J. curcas (5.90) and cowpea (0.35). The other groups formed were composed of the treatments T7 and T13 (group II), T2, T1 and T8 (group III), T4, T10, T11 and T12 (group IV) and T5, T6, T3 and T9 (group V). Although the treatments T14, T7 and T13 were grouped in the QI of the bivariate analysis graph, the method does not consist in a cluster analysis. Thus, after applying the procedure of Ward, only T14 defined group I in Figure 2A and B.

The dendrogram A showed group II formed by T7 and T13, indicating similarity between the treatments, already suggested in the QI of the bivariate analysis. Considering all variables determined in the dendrogram B, T14 remained as the best combination between $J$. curcas and cowpea. In B, only three dissimilar groups formed, suggesting that the increase in the number of variables analyzed, simultaneously, favored the grouping of similar combinations and highlighted the divergent one, T14. 
Using the hierarchical clustering method allowed the observation of the effect of multivariate response of the intercropping system. Hierarchical methods are frequently used to discriminate groups of individuals with similar agronomic attributes. In the present study, it was applied to discriminate combinations with similar mean scores and generated coherent and consistent results.

The DEA index and the multicriteria decision support analysis of Copeland also led to coherent and consistent results. However, both are used to evaluate production systems by operational research, a research line of the production engineering. Consequently, further studies are needed on the processing of data of intercropping experiments in agriculture.

\section{CONCLUSION}

The index LUETOTAL, associated with bivariate graphical analysis or hierarchical cluster analysis, can be applied in the processing of data from any intercropping system.

\section{REFERENCES}

ANGULO MEZA, L.; BIONDI NETO, L.; SOARES DE MELLO, J. C. C. B.; GOMES, E. G. ISYDS - Integrated System for Decision Support (SIAD - Sistema Integrado de Apoio à Decisão): a software package for data envelopment analysis model. Pesquisa Operacional, v.25, n.3, p.493-503, 2005a.

ANGULO MEZA, L.; BIONDI NETO, L.; SOARES DE MELLO, J. C. C. B.; GOMES, E. G.; COELHO, P. H. G. Free software for decision analysis: a software package for data envelopment models. Anais... In: 7th International Conference on Enterprise Information Systems - ICEIS 2005b, v.2, p.207-212.

BARROSO, A. C.; RESENDE, A. C.; RODRIGUES, W.; PAIXÃO, A. N. Viabilidade financeira e análise de risco do cultivo de pinhão manso para produção de biodiesel no estado de Tocantins. Revista em Agronegócios e Meio Ambiente, v.7, n.1, p.61-81, 2014.

BEZERRA NETO, F.; GOMES, E. G. Índices de desempenho de sistemas agrícolas consorciados: uso eficiente da terra, indicadores econômicos e eficiência dea. In: XXVIII Encontro Nacional de Engenharia de Produção - ENEGEP 2008. Anais... Rio de Janeiro, 2008, $1-10 p$.

BEZERRA NETO, F.; GOMES, E. G.; NUNES, G. H. S.; OLIVEIRA, E. Q. Desempenho de sistemas consorciados de cenoura e alface avaliados através de métodos uni e multivariados. Horticultura Brasileira, v.25, n.4, p.500-506, $2007 \mathrm{~b}$.

BEZERRA NETO, F.; GOMES, E. G.; NUNES, M. V. R.; BARROS JUNIOR, A. P. Análise multidimensional de consórcios cenoura-alface sob diferentes combinações de densidades populacionais. Pesquisa Agropecuária Brasileira, v.42, n.12, p.1697-1704, 2007a. 
BEZERRA NETO, F.; GOMES, E. G.; OLIVEIRA, A. M. Produtividade biológica em sistemas consorciados de cenoura e alface avaliada através de indicadores agroeconômicos e métodos multicritério. Horticultura Brasileira, v.25, n.2, p.193-198, 2007 c.

CAMILI, E. C.; AZEVEDO, C. C. B. V.; BOCUTI, E. D.; SILVÉRIO, J. M.; BARROS, K. C.; SILVA, A. R. B.; SEABRA, S. Cultivo consorciado de alface sob diferentes arranjos espaciais e manejo do dossel de taioba. Revista Agrarian, v.6, n.20, p.110-120, 2013.

CARDOSO, M. J.; MELO, F. de B.; ANDRADE JÚNIOR, A. S. de. Densidade de plantas de caupi em regime irrigado. Pesquisa Agropecuária Brasileira, Brasília, v.32, n.4, p.399-405, 1997.

CHARNES, A.; COOPER, W. W. Programming with linear fractional functionals. Naval Research Logistics Quartely, v.9, n.3, p.181-185, 1962.

COOPER, W. W.; SEIFORD, L. M.; ZHU, J. Handbook on data envelopment analysis. Boston: Kluwer Academic Publishers, 2004, 608p.

DIAS, L. A. S.; BARROS, W. S. Biometria experimental. Viçosa: Suprema, 2009, 408p.

DIAS, L. A. S.; LEME, L. P.; LAVIOLA, B. G.; PALLINI, A.; PEREIRA, O. P.; DIAS, D. C F. S.; CARVALHO, M.; MANFIO, C. E.; SANTOS, A. S.; SOUSA, L. C. A.; OLIVEIRA, T. S.; PRETTI, L. A. Cultivo de pinhão manso (Jatropha curcascurcascurcas L.) para produção de óleo combustível. Viçosa: UFV, 2007, 40p.

FEDERER, W. T. Statistical design and analysis for intercropping experiments. New York: Springer-Verlag, 1993, 298p.

FISHER, R. A. The design of experiments. 9 ed., London: Macmillan, 1971, 250p.

GOMES, E. G.; BEZERRA NETO, F. Método de apoio a decisão em experimentação agrícola: o caso de sistemas consorciados. In: XI SIMPÓSIO DE PESQUISA OPERACIONAL E LOGÍSTICA DA MARINHA - SPOLM, 2008, Rio de Janeiro. Anais..., p.1-12, 2008.

Instituto Brasileiro de Geografia e Estatística (IBGE). Levantamento sistemático da produção agrícola - LSPA (1997 - 2006). Disponível em

www.ibge.gov.br/home/estatistica/indicadores/agropecuaria/lspa/. Accessed on: September 15, 2015.

KAUSHIK, N.; KUMAR, K.; KUMAR, S.; KAUSHIK, N.; ROY, S. Genetic variability and divergence studies in seed traits and oil content of Jatropha (Jatropha curcascurcascurcas L.) accessions. Biomass and Bioenergy, v.31, n.7, p.497-502, 2007.

LOVELL, C. A. K.; PASTOR, J. T. Radial DEA models without inputs or without outputs. European Journal of Operational Research, v.118, n.1, p.46-51, 1999.

MATOS, F. S.; CARVALHO, D. D. C.; SOUZA, A. C.; NEVES, T. G; CRUVINEL, C. K. L.; ROSA, V. R.; SANTOS, P. G. F. Viabilidade agronômica do consórcio entre pinhão manso e soja. Revista Agrarian, v.7, n.24, p.226-232, 2014.

MELO, J. C. C. B. S.; MEZA, L. A.; GOMES, E. G.; NETO, L. B. Curso de análise de envoltória de dados. In. XXXVII Simpósio Brasileiro de Pesquisa Operacional, Gramado, 2005. Anais... Corumbá, 2005, p.2520-2547. 
MULLER, M. D.; PACIULLO, D. S. C.; MARTINS, C. E.; ROCHA, W. S. D.; CASTRO, C. R. T. Desenvolvimento vegetativo de pinhão-manso em diferentes arranjos de plantio em sistems agrosilvopastoris. Pesquisa agropecuária brasileira, v.49, n.7, p.506-514, 2014.

PEARCE, S. C.; GILLIVER, B. Graphical assessment of intercropping methods. Journal of Agricultural Science, v.93, n.1, p.51-68, 1979.

R Core Team. R: A language and environment for statistical computing. R Foundation for Statistical Computing, Vienna, Austria. 2014. URL http://www.R-project.org/.

SILVA, J. A. N.; SOUZA, C. M. A.; SILVA, C. J.; BOTTEGA, S. P. Crescimento e produção de espécies forrageiras consorciadas com pinhão-manso. Pesquisa Agropecuária Brasileira, v.47, n.6, p.769-775, 2012.

SOUZA, A. C.; RIBEIRO, R. P.; JACINTO, J. T. D.; CINTRA, A. D. A. R.; AMARAL, R. S.; SANTOS, A. C.; MATOS, F. S. Consórcio de pinhão manso e feijoeiro: alternativa para agricultura familiar. Revista Agrarian, v.6, n.19, p.36-42, 2013.

TEIXEIRA, L. C. Potencialidades de oleaginosas para produção de biodiesel. Informe Agropecuário, v.26, n.229, p. 18-27, 2005.

WARD, J. H. Hierarchical grouping to optimize an objective function. Journal of the American Statistical Association, v.58, n.301, p.236-244, 1963.

WILLEY, R. W. Intercropping - Its importance and research needs. Part. 1 - Competition and advantages. Field Crop Abstracts, v.32, n.01, p.1-10, 1979.

WILLEY, R. W.; RAO, R. A. Systematic design to examine effects of plant population and special arrangement in intercropping, illustrated by an experiment on chick pea/sunflower.

Experimental Agriculture, v.17, n.2, p.63-73, 1981. 